\title{
Peasant Empowerment Trough Quasi-Agrarian Reform Program, Evidence from Indonesia
}

\author{
Af Sigit Rochadi \\ Department of Sociology Universitas Nasional Jakarta-Indonesia \\ sigitrochadi@yahoo.com,siroabadi@gmail.com
}

\begin{abstract}
This article introduces the concept of quasi agrarian reform and critique of the de Soto theory of formal property. According to writer, agrarian reform, both redistribution and legalization of assets, must be run in Indonesia. The Indonesian government follows the de Soto theory by implementing the Farmers Empowerment Program. The objective of the quasi agrarian reform program is to encourage farmers to take credit in banks provided by the Government under the scheme Credit for the People (KUR).The importance of agrarian reform in Indonesia to empower farmers to solve various structural problems, such as poverty, unemployment and inequality. Implementation of an asset legalization program in this paper is called quasi agrarian reform, not in line with the original aspirations. Farmers prefer security in possession of land while the government wants it further that is the willingness of farmers to pledge their land in banks.
\end{abstract}

Keywords: Quasi-agrarian reform, agrarian reform, peasant empowerment, agrarian conflict, impoverishment of peasant

\section{Introduction}

In Indonesia, agrarian - reform becomes an actual issue of all time. Since this country was formed in 1945 until the leadership of President Joko Widodo, agrarian reform became one of the agenda. However, no government seriously manages the agenda so that its implementation is effective. The main difficulty is the lack of ideological support. Land reform program is interpreted by the political forces of Islam as a communist party program. While Islam is a religion shared by the majority of Indonesians (83\%) and communism is considered the main enemy. Islam-communist tensions have been going on since the 1920s and culminated in 1965. Throughout the New Order government (1966-1998), communism was also regarded as the main enemy. Attempts to investigate the mass killings of 1966-1968 against those accused of communist followers of the fall of the New Order were regarded as a revival of communism. Similarly, land reform or agrarian reform programs are also considered part of the leftist movement. Therefore, in the era of President Susilo Bambang Yudhoyono, land reform program has two variants, namely land redistribution and asset legalization. This second variant is called the quasi of agrarian reform.

Generally, agrarian reform has two objectives, namely to achieve justice and to increase farmer productivity. Because the two objectives have not achieved, agrarian reform is an interesting issue of all time. This issue had appeared prior to the independence of Indonesia and was a matter of debate among the independence activists. After the independence, narrowed as land reform, agrarian reform became the left and center- left ideology promoted by the Indonesian Communist Party (PKI), the Murba Party and the radical Indonesian National Party. Cabinets that came and went in the era of the Old Order (1945-1965) were also resulted from the expertise of political parties to exploit the issue of agrarian reform. The actions of The Indonesian Peasant's' Front (BTI) and the Indonesian Forestry Workers Union (SERBUKI), mass organizations affiliated with the PKI in 1963-1965, leading to class conflict in rural areas and triggering the 1965 coup, ended debates and discourses on agrarian reform. Moreover, the New Order government adopted the ideology of "developmentalism", which did not require people's participation in development, the agrarian reform discourse disappeared from the political stage of Indonesia. As a result, once being the country's principal program under Law no. 5 of 1960 and Law No. 56 of 1960, agrarian reform was only treated as a routine daily bureaucratic affair (Wiradi, 2000). It was surprising that the spirit of agrarian reform emerged after the New Order with the stipulation of TAP MPR No. IX/ MPR/2001. The government was mandated by the people to implement agrarian reform to resolve agrarian conflicts and to implement agrarian reforms through land redistribution prioritized for the poor. The euphoria situation over the success of the people and student movements overthrew Suharto temporarily built elite cohesiveness. This situation allowed populist agenda to enter into state policy. In the New Order period, agrarian reform to refer to restructuring tenure, use, ownership and utilization of agrarian resources for the justice and welfare of the people was only voiced by peasant movements. According to Rosser's interpretation(Rahman, 2012), the MPR TAP is one of the 
phenomenal examples of the work of reformist forces in democracy. However, President Abdurrahman Wahid and Megawati Soekarnoputri did not set an agenda for the implementation of TAP MPR IX/2001 and the Basic Agrarian Law (UUPA). Moreover, Megawati disappointed the agrarian reform activists by issuing Presidential Decree No. 34/2003 in order to revise the 1960 UUPA.

In contrast, President Susilo Bambang Yudhoyono (SBY) designed the National Agrarian Reform Program as required in TAP MPR IX/2001 by setting an agenda for a land redistribution of 8.15 million hectares. This design did not run well due to weak coordination between ministries and weak presidential leadership that the president did not stand at the front leading the change and tended to let every ministry running its own agenda. As suggested by Groenewald (Groenewald, 2004)and Binswanger-Mkhize (Binswanger-Mkhize, 2014), the success of agrarian reform requires a radical change in the design and implementation, active participation of beneficiaries and strong implementing organizations by siding to landless peasant. During 2012-2014, only 420,180 plots of land were successfully redistributed land, which were smaller in the previous years. In addition to low political will, the achievement was very much lower than the target because of a half-hearted leadership of SBY. Nevertheless, his leadership successfully launched a new formula of agrarian reform, namely asset reform and access reform. This article discusses agrarian reform in terms of asset reform in the perspective of peasant empowerment. The question that guides this article are, why does the government need to undertake asset reform? What are the benefits of implementing the program for peasants and what are the risks borne by peasants? In order to answer those questions, a conceptual study of community empowerment, agrarian reform and asset reform was conducted respectively.

\section{Literature Review}

In developing countries, land reform is very important to realize farmers' justice and prosperity. The imbalance of ownership and control of land in developing countries is very serious. In Indonesia, restrictions on land ownership are regulated in law no. 5 years 1960, but its implementation is weak. The government does not have the political will to explicitly implement the law which affects more and more landless peasants. According to the Agricultural Census of 1973, the number of landowners is $74.7 \%$. This figure in 2003 decreased to $70.5 \%$. In contrast, landless farmers increased from 3.2\% to 3.4\%(Bachriadi \& Wiradi, 2011). Agrarian reform is reforming ownership, tenure and use of land to achieve justice and increase productivity primarily for small and landless peasants. In The Peasants' Charter (FAO, 1981), agrarian reform is a movement, which means an ongoing effort to create justice for peasants. Agrarian reform is not a momentary, but sustainable effort of which ultimate goal is to achieve justice and increase farmer productivity. According to Jacobs (Jacobs, 2010), land reform for the benefit of peasants does not have a meaning of reform if it is not followed by efforts to reduce peasants' poverty, food security and agricultural sustainability. Both the Peasants' Charter and the Jacobs' concept have meaning consisting of asset reform and access reform. This was developed by the National Land Agency (BPN) under Joyo Winoto(Winoto, 2013). In a narrow sense, agrarian reform refers to land reform, which is a restructuring of land tenure and ownership, especially the land redistribution aimed at achieving equity in agricultural development (Tuma, 1966). This is what is called genuine agrarian reform. However, in the broader sense, land reform is the same as agrarian reform, that is: "An attempt to improve agrarian structure consisting of land tenure system, methods of cultivating land and business organization, scale of business operation, rent, village credit institutions, marketing, education and training to adapt to justice and productivity objectives" (Tuma, 1966).

After conducting studies in several countries, Winoto(Winoto, 2013) states that there are 4 (four) categories of agrarian reform, namely radical land reform, land restitution, land colonization and market-based land reform. The first category is difficult to implement because the political forces supporting this concept are getting smaller. Moreover, unilateral events in 1963-1965 left a traumatic experience for Indonesia. The second category worked in several locations, such as the former land of PT Sari Petung in Kediri and the former mining land in Bangka Island. Meanwhile, the third category was implemented in the form of transmigration, although since the fall of the New Order the format has changed to designate more for local residents. For the fourth category, land reform was carried out based on or with the help of market mechanisms that could take place if land title was given so that security in tenure works to encourage financial markets in rural areas. This is what is popularly referred to asset legalization program. However, due to the absence of reform in land ownership, tenure and redistribution, agrarian reform has lost its 
meaning. Therefore, this article uses quasi or pseudo because there is no change in structure and only change in function. This concept is different from that is proposed by Christodoulou (Wiradi, 2000) who positions such agrarian reform as fabianism, an imprecise analogy because fabianism is a slow-down by pretending to do but actually not. For the government, quasi-reform has various benefits such as that agrarian reform program continuously exists, state apparatus continuously work and state budget can be continuously spent. For landowners, its usefulness is still determined by various objective factors beyond the control of the landowners.

Based on the aforementioned definitions, agrarian reform also includes empowerment or strengthening of peasants. Through the asset legalization, land will have a wider function and be connected with larger socioeconomic system. There is a strong correlation between legal assets and land prices or economic value of the land. According to classical economic theory, the key to social progress is in the capital formation and only the owners of capital and landowners are able to do so (Jhingan, 2012). As capital, land will only have value if it is integrated widely with economic system. This means it requires change from extralegal property to formal property. Without such change, land is only dead capital and remains in the extralegal domain as well as fails as capital (Soto, 2006). By placing the land in the position of formal property, the land owner will reach the position of empowerment by actualizing himself in social system of society. In this context, empowerment must avoid the strengthening of individuals only, but must maintain and develop social institutions and social systems of society. In Friedman's concept, strengthening the ability of individuals and social institutions is to achieve independence (local self-reliance (but not autarchy)(Friedman, 1992). There are a number of benefits to landowners by placing their land in the position of formal property, namely managing economic potential of the asset, integrating it into a socioeconomic system, strengthening the responsibilities of participants in the existing system, placing more liquid assets to be easily interchangeable, placing the participants in one network and, equally important, protecting transactions, not only protecting assets(Soto, 2006). If the asset remains in the extralegal position, the owner runs a considerable risk of losing security against ownership, property protection costs greater than taxes and placing the property in an underground position so that it is often neglected in public services (Soto, 2006).

Such empowerment strategies contain fundamental weaknesses, such as the danger of "new right" and neoliberalism. Integrating local resources into global capitalist economic system will accelerate the transformation to neoliberalism and transform social resources into marketable private goods (Ife \& Tesoriero, 2006). The danger of new right includes reducing the role of the state, the role of the community and placing individuals and families as the main actors in development. In Indonesia the implementation of landreform was held in 1961-1965. The leftist political power led by the Communist Party of Indonesia (PKI) is impatiently awaiting the rules of implementing land reform and undertaking unilateral action against stateowned lands and clerics (ulama). As a result, there was an open tension and conflict that claimed the lives of more than 500,000 people accused of PKI followers. The military's efforts to create stability were carried out by arresting those accused of PKI followers and imprisoning them for 15 years without trial. The attempt to make agrarian arrangements of any kind, immediately led to resistance from the right group, especially from the conservative Islamic forces. This ideological challenge causes program implementation to be very complicated.

\section{Methodology}

This research employed secondary data analysis. This method analyzes data collected by others, government agencies or other institutions concerned about an issue. Over the last two decades social scientists have made use of this method because of extensive data, low cost and allowing comparison analysis (Neuman, 2014). The data analyzed were taken from the Ministry of Agrarian Affairs and Spatial Planning/National Land Agency, Central Bureau of Statistics, and agencies or institutions concerned with agrarian affairs. The data were analyzed by comparing and interpreting quantitatively and descriptively.

\section{Results and Discussion}

Agrarian reform in Indonesia is very important and urgent to implement. The importance of agrarian reform to overcome problems of imbalance in land ownership, poverty, unemployment, environmental damage and 
lack of food supply. Approximately $40 \%$ of lands in Indonesia is controlled by private companies and individuals. Total area of land under Rights to Cultivate (HGU), Logging Concession (HPH), Industrial Plantation Forest (HTI) and Building Right on Land (HGB) until the end of 2016 reached 41.21 million hectares. Meanwhile, the number of peasants, owning landless than 0.25 hectares, were 13.7 million people. Inequality of land title and ownership between layers is indicated by the Gini index of 0.562 (data of 2012). A total of 17.17 percent of peasant households owned only 0.9 percent of agricultural land. Of course, such size of agricultural land is not efficient to work on because the expenditure of energy, goods and money was not equivalent to the production. As a result, most peasants were caught in a cycle of increasingly severe poverty. Inequality of agricultural land tenure is very serious. $11.27 \%$ of peasant households control $45.47 \%$ of agricultural land with an area of 2 hectares or more, while peasants who own land that does not meet the economic scale for production reach 56.41\%. This figure does not meet the Porsterman index for peasant revolution because they are not landless. However, it is clearly an arena of continuing agrarian conflict. In any sector, the conflict always put peasants powerless, especially when dealing with corporations and the state (state enterprises). The Agrarian Reform Consortium (KPA) records that every year there is an increase in agrarian conflicts in terms of number, area of the land, injured families and criminalized peasants (Table 1).

Table 1: Number of Cases and Area of Agrarian Conflict in Indonesia 2013-2016 (Ha)

\begin{tabular}{llllllll}
\hline No & Sector & $\begin{array}{l}\mathbf{2 0 1 3} \\
\text { Case }\end{array}$ & Area & $\begin{array}{l}\mathbf{2 0 1 4} \\
\text { Case }\end{array}$ & Area & $\begin{array}{l}\mathbf{2 0 1 6} \\
\text { Case }\end{array}$ & Area \\
\hline 1 & Plantation & 180 & $527,939.27$ & 185 & $924,740.09$ & 163 & 601,680 \\
2 & Mining & 38 & $197,365.90$ & 14 & $6,953.00$ & 28 & 45,588 \\
3 & Infrastructure & 105 & 35,466 & 215 & $74,405.16$ & 100 & 35,824 \\
4 & Forestry & 31 & 545,258 & 27 & $271,544.00$ & 25 & 450,215 \\
5 & Coast/Waters & 9 & NA & 4 & $1,548,150.00$ & 10 & 1,706 \\
6 & Property & NA & NA & NA & NA & 117 & 104,379 \\
7 & Agriculture & NA & NA & NA & NA & 7 & 5 \\
& Total & 369 & $1,281,660.09$ & 472 & $2,860,977.07$ & 450 & $1,265,027$ \\
\hline
\end{tabular}

Source: Agrarian Reform Consortium, 2017

In addition to the aforementioned two problems, poverty is also an urgent issue to overcome. In 2014, the number of poor people was 28.28 million or 11.25 percent of the population of Indonesia. This figure changed to 28.59 million or 11.22 percent of the total population of this country in 2015(BPS, 2016). If classified by areas, 18.29 million of poor people live in rural areas. Broadly speaking, the characteristics of the poor group are poorly educated, without land to work on, some women as family heads, subsistence living, without permanent jobs, if working mostly as land tenants or domestic workers and are vulnerable to socioeconomic changes. Such characteristics are not able to join the asset legalization program because they do not have it. Protection policy is needed, not empowerment, for people with such characteristics such as giving land either in the terms of radical land reform as implemented in 1961-1965 or land restitution and land colonization.

Table 2: Redistributed Land Area and Number of Heads of Families Receiving Land

\begin{tabular}{lll}
\hline Year & Area (Ha) & Number of Receiver (Head of Family) \\
\hline $1961-2004$ & $1,153,685$ & $1,504,572$ \\
2005 & 5,560 & 6,510 \\
2006 & 7,527 & 4,924 \\
2007 & 91,969 & 78,311 \\
2008 & 284,087 & 220,212 \\
2009 & 176,198 & 169,110 \\
2010 & 150,499 & 152,538 \\
2011 & 181,429 & 111,762 \\
2012 & 126,662 & 91,687 \\
2013 & 159,480 & $\mathrm{Na}$ \\
2014 & 138,181 & $\mathrm{Na}$ \\
Total & $2,475,211$ & $2,339,626$ \\
\hline
\end{tabular}

Source: National Land Agency (data processed) 
In contrast, peasants who joined the quasi-agrarian reform program were relatively constant every year. Of the six types of programs implemented by the National Land Agency, a program involving peasants are PRONA (Agrarian National Operation Project) and Agriculture. Prona had been implemented since 1981 initially targeting the poor in rural areas and then expanded to veterans, employees whose salary below the provincial minimum wage and widow/widower of retired civil servant. As a project known to the public, Prona was more attractive and its requirements were not as complicated as other programs. In joining a program including empowerment, people paid attention to relative advantages, suitability, complexity, testable and ability to observe a curve building. In addition to these factors, public participation in the Prona program was inseparable from the considerable scope of the program compared to other programs.

Table 3: Asset Legalization in 2012-2014

\begin{tabular}{lllll}
\hline No & Type of Program & $\mathbf{2 0 1 2}$ & $\mathbf{2 0 1 3}$ & $\mathbf{2 0 1 4}$ \\
\hline 1 & Prona & 745,540 & 770,075 & 734,825 \\
2 & Agriculture & 27,671 & 22,519 & 23,265 \\
3 & Transmigration & 23,453 & 5,976 & 17,286 \\
4 & SMEs & 18,973 & 19,192 & 18,616 \\
5 & Fishermen & 13,431 & 16,527 & 23,813 \\
6 & Low-Income People & 6,415 & 7,037 & 7,350 \\
& Total & 835,483 & 841,326 & 825.155 \\
\hline
\end{tabular}

Source: LAKIP BPN-RI 2013, 2014, 2015. Data 2015 are not specified.

Meanwhile, agricultural program was specifically made for peasants. The participation rate of this program was very low compared to the existing land area. According to the Ministry of Agriculture, in 2013 the area of agricultural land in Indonesia was 39.4 million hectares in which rice field was only 8.1 million hectares (20.5\%) (Kementan,2014). Of this area, only about $44 \%$ had been certified. If the annual number of legal asset participation was only about 24 thousand parcels of land, every district/city in Indonesia was only able to certify 46.7 parcels of land annually, provided that there are 514 regencies/cities in Indonesia. This figure is very small compared to the existing resources. It was more ironic if sources of cost were taken into consideration. For example, data of 2015 mention that 2,147,490 land parcels were successfully certified (ATR/BPN, 2016). Of these figures, the State Budget only covered 858,999 areas, the rest (59.9\%) from NonTax Revenue (PNBP) or funded by the community itself. Annually, there were only about 106 thousand owners of land certificate who joined the access reform program (ATR/BPN, 2016). This participation rate was very low if compared to the number of participants on the asset legalization. The low number of participation in the access reform, according to the BPN research results in 4 (four) provinces (West Java, South Kalimantan, Gorontalo and Southeast Sulawesi), was due to low public interest in participating the access reform, especially getting bank credit to establish small businesses. Meanwhile, Agricultural Research and Development (R \& D) to increase agricultural productivity found that such low interest was because peasants did not know that credit was given from banks to peasants. On average, People Business Credit (KUR) for agriculture sector was only absorbed by 15\% every year from the total KUR of 100-120 trillion rupiahs. More than $65 \%$ of credits were absorbed in the trading sector.

This indicates that information was not disseminated properly among peasants. In the theory of program implementation, dissemination and communication are the main variables. The discovery of this problem indicates sectorial ego of the ministry. The success of the credit program for farmers was determined by 4 (four) actors, namely the National Land Agency (for land affairs), Ministry of Agriculture (for farmer's affairs), Ministry of Cooperatives and SMEs (for business types that will be developed) and the Ministry of Finance (credit value). However, they avoided final responsibility of the program and dissemination in order to avoid expenditures from their respective posts. Such weak coordination and strong sectorial ego show that the welfare of the people has not become a common goal of the government apparatuses. This coordination problem was also revealed in a research conducted by NK Agustin, Yulia F. Sinuraya and Sahat M Pasaribu on "Land Certification and Food Production Improvement in 2012 in 7 provinces". Involving 1,350 respondents, this research indicates that tension between actors took place starting from the process of land certification until the effort to get bank credit. In the process of certification, the tension occurred when determining prospective peasant prospective location. BPN determined specific location and the Ministry of Agriculture determined prospective peasants and they were not synchronous. This tension had implications in the budget 
(NK Agustin, 2012). Here, the Coordinating Minister, Governor and Regent/Mayor were not able to establish harmony and cooperation for optimizing results.

The main objective of the farmers joining land certification was to obtain clarity of land ownership status so that they felt secure and had evidence according to the written law. In addition, peasants had the opportunity to participate in access reforms made by BPN and prevent land occupation and land use change (NK Agustin, 2012). Nevertheless, Agustin et al. did not find a direct correlation between land certification and increased agricultural productivity. Productivity was more affected by technology, input use and farmer behavior. If the rising price of land after the certification was interpreted as productivity, the goal of certification was achieved. Agricultural areas close to industrial areas would increase the value of rapidly and, without strong legal protection, land was easily transferable through unilateral occupation or illicit sale. In line with the findings of Agustin et al. above, similar motivations were demonstrated by the research conducted by Jones (Jones, 2010) in Southeast Asia, Thontteh and Omirin(Omirin, 2015)in Lagos and Geininger and Feder(Feder, 2009)in a number of developing countries. David Jones points out that the need to clarify the status of the land and obtain legal protection from the state were the main motivation of the people in Southeast Asia to join the land certification program. Although its impact on the economic changes of families was small, participants joined such program enthusiastically. Three major issues that obstructed the asset legalization program were poor governance standards, less positive responses from traditional communities and the domination of political and business elites in land tenure. The impacts that occurred in Lagos as reported by Thontteh and Omirin were increased public confidence in land-based transactions. The economy of Lagos would make rapid progress if it was able to eliminate three major obstacles related to land, namely institutions, clear legal framework and professionalism of land staff. The findings of Geininger and Feder were more specific that there was an increase in investment and community productivity, including farmers. The amount of credit disbursed also increased significantly and had an impact on the increase of people's incomes. However, some new conflicts over claims and reclaiming of certified land so that they rejected de Soto's thesis that formal property was not a panacea in economic development.

Other micro-studies on the impacts of quasi-agrarian reform show that there was no increase in farmers' income. A study conducted by Asliah Amir revealed that the decision of farmers to utilize land certificates for collateral was affected by various factors, namely land area, amount of credit obtained, loan lending procedure in bank, and credit payment system (Puswanhari, 2012). A study conducted by Puswanhari revealed that only $14 \%$ of respondents used land certificates as collateral in banks. Involving respondents in urban areas, this study shows respondents' understanding about the intricacies of borrowing money in the bank so that he main motivations to give the land certificate as collateral were obtaining the loan easily, utilizing assistance from the government, avoiding complicated matters with the bank and obtaining certainty of land prices and obtaining the loan. Those motivations indicate that respondents had experience related to financial institutions, both banks and non-banks.

\section{Conclusion and Recommendations}

Peasant empowerment through agrarian reform programs is urgently implemented by the Government to resolve fundamental structural problems such as poverty, inequality, unemployment, declining food supplies, land conflicts and environmental damage. Land redistribution, especially to poor families, needs to be immediately realized to prevent the aforementioned problems from being acute. Being expected to improve the welfare of peasants, the quasi-agrarian reform program did not meet expectations. There was no direct correlation between land certification and peasant's credit participation. Direct correlation was shown by the rising land prices after the certification. There were a number of "intermediate variables", such as need for business, value of the land, credit contract process and business scale to be developed. The peasants' primary needs for land certification were to obtain a sense of security, to serve as a strong evidence of land ownership, to preserve the opportunity to at any time join the access reform and to prepare for land speculators, especially in areas of rapid economic development. The cost of implementing the land certification program was mostly borne by the community. Such cost problem was also an obstacle, especially for families who were not covered by the Prona program. The negative impact of this program was indicated by increased agrarian conflicts, especially for peasants who were unable to develop their business and unable to pay off bank loans. Peasants' lands were forced into the land market and fell into the hands of money owners. In such 
situations, the implementation of the quasi-agrarian reform program promoted the neoliberal ideology that trapped peasants to lose their land. Taking note of these findings, this study recommends (1) the need to be cautious in giving credit to farmers. Farmers who do not have the business to be excluded from the credit program. (2) the empowerment of farmers through the quasi-agrarian reform program needs to be continued because it provides great benefits to farmers, especially to protect their property.

\section{References}

ATR/BPN, K. (2016). Laporan Akuntabilitas Kinerja Instansi Pemerintah Kementrian ATR/BPN Tahun 2015 (Performance Report of Government Institution Ministry of ATR / BPN Year 2015). Kementrian ATR/BPN.Jakarta

Binswanger-Mkhize, H. P. (2014). From Failure to Success in South African Land Reform. African Journal of Agricultural and Resource Economics, 9(4), 253-269.

BPS. (2016). Indikator Kesejahteraan Rakyat 2015 (Indicator of People's Welfare 2015). BPS. Jakarta

FAO. (1981). The Peasants' Charter. FAO. Rome

Feder, K. D. (2009). Land Registration, Governance, and Development: Evidence and Implication for Policy. World Bank Research Observer, 1(1), 233-266.

Friedman, J. (1992). Empowerment: The Politics of Alternatif Development. Blackwell. Cambridge

Groenewald, J. A. (2004). Conditions for Successful Land Reform in Africa. South African Journal of Economic and Management Sciences, 7(4), 673-704.

Ife, J. \& Tesoriero, F. (2006). Community Development: Community-Based Alternatives in an age of Globalisation.Pearson Education. Ottawa

Jacobs, S. (2010). Agrarian Reform. Current Sociology, 61(5-6), 862-885.

Jhingan, M. (2012). Ekonomi Pembangunan dan Perencanaan (Economic Development and Planning). PT RajaGrafindo Persada. Jakarta

Jones, D. S. (2010). Landregistration and Administrative Reform in Southeast Asian States: Progress and Constrains. International Public Management Review, 11(1), 67-89

Kementan (2014). Statistik Lahan Pertanian Tahun 2009-2013 (Agricultural Land Statistics Year 2009-2013). Pusat Data \& Sistem Informasi Kementan. Jakarta

Neuman, W. L. (2014). Metode Penelitian Sosial: Pendekatan Kualitatif dan Kuantitatif (Social Research Methods: Qualitative and Quantitative Approaches). PT. Indeks.Jakarta

NK Agustin, J. F. (2012).Sertipikasi Lahan Pertanian Mendorong Peningkatan Produksi Pangan (Agricultural Land Certification Encourages Increased Food Productions).Litbang Pertanian. Jakarta

Tontteh, E. O. \& Omirin, M. M. (2015). Land Registration Within the Framework of Land Aministration Reform in Lagos State. Pasific Rim Property of Recearch Journal, 21(2), 161-177.

Puswanhari, D. S. (2012). Faktor-Faktor Dominan Pemanfaatan Sertifikat Tanah Sebagai Jaminan Kredit Perbankan oleh UMK (Dominant Factors of Utilization of Land Certificate as Credit Guarantee Banking by MSEs). Universitas Indonesia. Jakarta.

Rahman, N. F. (2012). Land Reform dari Masa ke Masa (Land Reform from Time to Time). Tanah Air Beta. Yogyakarta.

Soto, H. D. (2006). The Mystery of Capital: Rahasia Kejayaan Kapitalisme Barat. Qalam. Jakarta

Winoto, J. (2013). Reforma Agraria di Indonesia, Bunga Rampai (Agrarian Reform in Indonesia). Worldpress. Yogyakarta.

Wiradi, G. (2000). Reforma Agraria Perjalanan yang Belum Berakhir (Agrarian Reform Unfinished Journey). Insist. Yogyakarta.

Tuma, E. T. (1966). Twenty-Six Centuries of Agrarian Reform: A Comparative Analysis. University of California Press. California. 